\title{
Brazilian Business Cycles and Growth from 1850 to $2000^{+}$
}

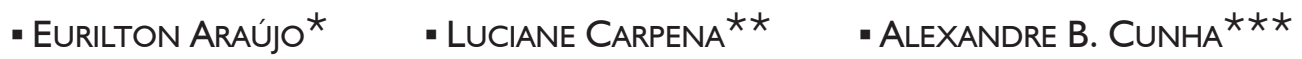

\section{RESUMO}

Estudaram-se neste artigo as propriedades do produto interno bruto per capita brasileiro de I850 a 2000. Contrariamente ao observado em alguns países desenvolvidos, não se obteve evidência de alterações expressivas na volatilidade do PIB per capita. Contudo, verificou-se que as oscilações na atividade econômica se tornaram mais persistentes após a $2^{a}$ Guerra Mundial.

\section{Palavras-Chave}

PIB per capita, ciclo de negócios, crescimento, Brasil

\begin{abstract}
We study the cyclical and growth properties of Brazilian per capita output from I850 to 2000. We find that, contrary to some developed countries, Brazil did not experience large changes in the volatility of per capita output. However, we obtained evidence that the oscillations in economic activity became more persistent after World War II.
\end{abstract}

\section{KEYWORDS}

per capita GDP, business cycles, growth, Brazil

\author{
JEL CLASSIFICATION \\ $C 22, E 32, N 10$
}

$+\quad$ This paper highly benefited from comments by two anonymous referees. Financial support from the Brazilian Council of Science and Technology (CNPq) is gratefully acknowledged.

* IBMEC São Paulo. Corresponding author address: Rua Quatá, 300 - São Paulo, SP - Brazil - 04546-042. E-mail: euriltona@isp.edu.br.

** Faculdades IBMEC/RJ e BNDES. Corresponding author address: Av. Pres. Wilson, $118,2^{\circ}$ andar - Rio de Janeiro, RJ - Brazil - 20.030-020.

$\star \star \star$ Faculdades IBMEC/RJ. Corresponding author address: Av. Pres. Wilson, II8, sala III9 - Rio de Janeiro, RJ - Brazil - 20.030-020. E-mail: research@alexbcunha.com.

(Recebido em abril de 2005. Aceito para publicação em agosto de 2007). 


\section{INTRODUCTION}

The reporting of empirical regularities of economic time series has a long tradition in the study of business cycles and economic growth. For instance, Burns and Mitchell (1946) documented several features of the economic cycles in the United States. In the field of economic development, Kaldor's (1961) summary of some growth evidence became widely known as Kaldor's stylized facts.

Recently, several papers have sought to document the statistical properties of business cycles. Backus and Kehoe (1992) and Hodrick and Prescott (1997) are typical examples of this research line. The same research strategy has been followed in the field of economic growth. For instance, Barro and Sala-I-Martin (1995) devoted several chapters of their book to studying of the empirical regularities of economic growth.

While the international literature on the statistical regularities of business cycles and economic growth is very large, its Brazilian counterpart is relatively incipient. One of the reasons is that the lack of available data often restrains studies of Brazilian business cycles to the period after World War II, as in Ellery Jr., Gomes and Sachsida (2002).

We have two main goals in this paper. The first is to construct long GDP and per capita GDP series for the Brazilian economy to be able to compare the statistical properties of these series to the stylized facts provided by Backus and Kehoe (1992) and other international evidence. The second is to investigate the nature of structural changes that may have taken place over time. We place particular emphasis on the study of volatility, persistence and the relation between growth and volatility.

We construct GDP and per capita GDP series for the Brazilian economy that covers the period 1850-2000. ${ }^{1}$ We combine data from Goldsmith (1986), Haddad (1978) and IBGE (2003) to construct our GDP series. Those sources cover, respectively, the periods 1850-1900, 1900-1947 and 1947-2000. We then use information from IBGE (2003) to generate a population series. We provide additional details about our data set in Section I.

We evaluate some basic business cycle features, such as volatility, persistence, turning points, and the length of recessions and expansions of the per capita GDP series. We assess some of these features over distinct sub-periods of the whole sample and

1 Ellery Jr. and Gomes (2005) have recently managed to construct series for GPD and other macroeconomic variables such as consumption and investment for the Brazilian economy that cover the entire twentieth century. The GDP series we present in this paper is longer than that of Ellery Jr. and Gomes. 
compare our findings with the international evidence. We also study the volatility and the persistence of the per capita GDP growth rate.

Our main findings are that, unlike the evidence Backus and Kehoe (1992) presented for several industrialized nations, the volatility of Brazilian business cycles did not vary greatly over the sub-periods of our sample. We also show that volatility may be characterized by three phases. There is an initial low volatility period from 1850 to 1875. Then, in an intermediate period, lasting up to 1975, the Brazilian economy displayed high volatility. Finally, low volatility characterized the period from 1976 to 2000 .

Concerning persistence, we obtain evidence that the cyclical component of the per capita output became more persistent after 1945. With respect to the relation between growth and volatility rates, we do not find a statistically significant relationship between these variables. However, we do find that there is a change in the dynamics of the series when we compare pre and post World War II periods. That change can be attributed to an increase in persistence rather than any abrupt change in volatility.

In summary, we provide evidence that the behavior of the volatility of the Brazilian business cycles from 1850 to 2000 was quite different from their counterparts in the US and some other developed economies. Contrary to the experience of those countries, the volatility of the Brazilian economy appears to have been roughly constant. Our analysis also shows that the persistence of the economic activity oscillations increased after the Second World War. Finally, we do not find a strong relation between economic growth and volatility.

We wish to stress the relevance of our findings. As Backus and Kehoe (1992) and Ellery Jr. and Gomes (2005) pointed out, a crucial question in international business cycles is whether countries display similar economic oscillations. We contribute to this issue by showing that Brazilian business cycles had some distinctive features. Authors such as Black (1987) and Caballero (1991) have argued that an increase in volatility should have some impact on growth and investment rates. We investigate whether this holds in the Brazilian economy and find that its growth was not significantly affected by economic volatility over the period 1850-2000.

This paper is organized as follows. In Section I we present our data set and evaluate its reliability. In Section II we test the GDP and per capita GDP series for non-stationary behavior. In Section III we study the business cycle properties of Brazilian per capita GDP. In Section IV we focus on the empirical relationship between vola- 
tility and growth. Finally, Section V contains our concluding remarks. In addition, we list our population, GDP and per capita GDP series in Section VI (Appendix).

\section{THE DATA SET}

In this section we explain how we construct our GDP series. We then explain how we obtain the population series. Concerning the per capita GDP series, we derive it by simply taking the ratio between the two former series. We also discuss the reliability of these series.

\subsection{The GDP Series}

Goldsmith (1986) contains a real GDP series from 1850 to 1900 (Table II.1, pages 22 and 23 and Table III.1, pages 82 and 83). Haddad (1978) provides data for the same variable from 1900 to 1947 (Table 3, page 15). The data CD that accompanies IBGE (2003) is the source for the sub-period 1948-2000. The files ' 1 _2_scn_consolidado.xls' and '1_3_nscn.xls', both located in the folder 'economia|contas_nacionais' of that CD, contain real GDP growth rates from 1948 to 2000. We combined these three sources to obtain a real GDP index from 1850 to $2000 .^{2}$

We now discuss some issues related to the reliability of our GPD series. As usual, the older the period, the less reliable the data are. In the particular case of our GDP series, the 1850-1900 sub-period deserves more attention.

From 1947 onwards, our data source is the official Brazilian national account system. The source for the 1900-1947 period is Haddad (1978). ${ }^{3}$ Despite not being an official GDP measure, Haddad's figures are widely accepted today. Thus, we can be fairly sure that no available series covering the 1900-2000 years is more accurate than ours.

As explained, we linked Haddad's series to Goldsmith's at 1900. We do not know of any other estimate of Brazilian GDP that covers the period 1850-1900. Thus, a strong reason to adopt the Goldsmith's series is the fact that it is the only one available. The exclusiveness of Goldsmith's GDP series does not ensure its accuracy. Thus, it is important to check this as far as possible. Contador and Haddad (1975) provided yearly estimations of Brazilian GDP from 1861 to 1900. Table 1 compares the GDP growth rates of those two series.

2 We present our GDP, population and per capita GDP series in Table Al in the appendix.

3 Note that the Brazilian national account system does not cover the period before 1947. 
TABLE I - COMPARISON OF GDP SERIES: AVERAGE GROWTH RATES

\begin{tabular}{lcc}
\hline Period & Goldsmith & Contador and Haddad \\
\hline $1862-1900$ & 1.61 & 1.47 \\
$1862-1870$ & 2.63 & 3.96 \\
$1871-1880$ & 1.60 & 1.98 \\
$1881-1890$ & 2.14 & 2.04 \\
$1891-1900$ & 0.19 & -1.75 \\
\hline
\end{tabular}

For the period 1862-1900, the two series have a similar average growth rate. For smaller intervals, the similarity is smaller. Goldsmith emphasized this point. He suggested that the short-run oscillations of any GDP series for that period should be evaluated with care.

We decided to adopt Goldsmith's series for two reasons. First, as mentioned, it is the only one that covers the period 1850-1900. Second, Goldsmith constructed his series using information from labor compensation, money supply, foreign trade and public spending, while Contador and Haddad used only foreign trade from 1861 to 1888 and foreign trade plus installed electric power capacity afterwards.

We summarize the above discussion as follows. Our GDP series has five properties:

1. As far as we know, it is the only series that covers the entire 1850-2000 period.

2. Authors such as Goldsmith (1986) and Ellery Jr. and Gomes (2005) have used Haddad's work in their measurement of Brazilian GDP over the 1900-1947 period. We use Haddad's latest estimates for the years in question.

3. Its data for the 1947-2000 sub-period are exactly the ones available from the official Brazilian national account system.

4. It provides an accurate description of the long-run evolution of Brazilian GDP.

5. Its short-term measurement errors should be larger in the 1850-1900 sub-period than later. 
To minimize the problem pointed out in the last item, on several occasions we report results for the whole period 1850-2000 and some selected sub-periods.

We plot the natural logarithm of the real GDP below.

\section{FIGURE 1 - LOG OF REAL BRAZILIAN GDP}

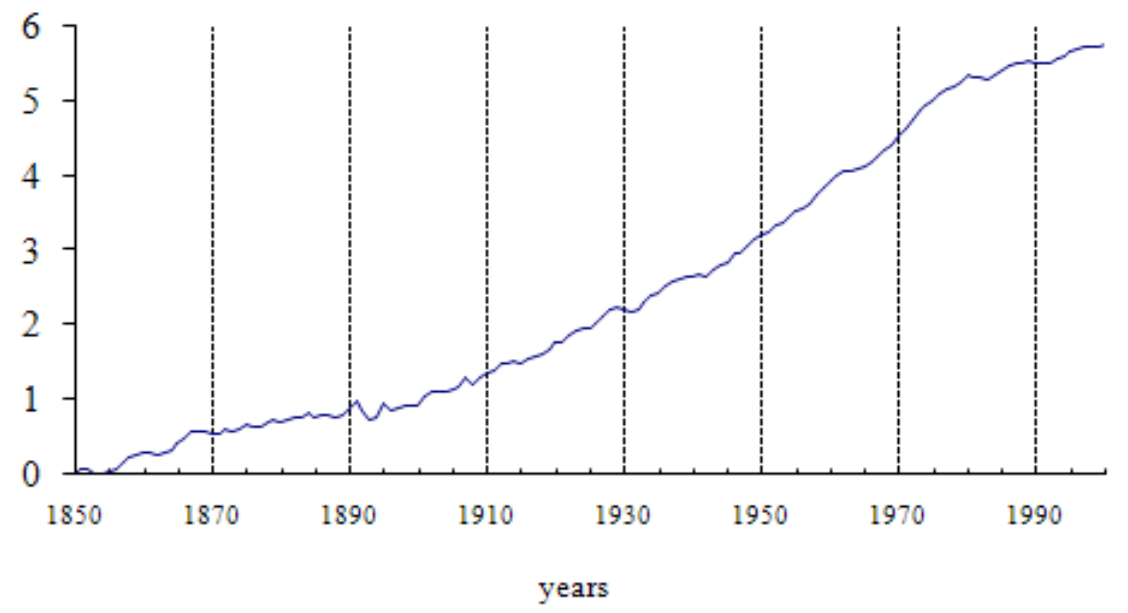

The period 1890-1895, which became known as the encilhamento, displayed large oscillations in economic activity. There was a sharp expansion from 1890 to 1892 , a deep recession in 1893 and 1894, and a strong recovery in 1895. According to Goldsmith (1986), the banking liberalization that took place with the advent of the Republic in 1889 triggered the initial expansion. A subsequent general banking crisis caused the ensuing recession.

The industrial machinery and equipment imports data provided in Table 7.6 of IBGE (1990) provide additional information on real economic activity for the encilhamento period. These data displayed positive growth in 1890 and 1891, a decrease in 1892, stagnation in 1893 and 1894 and recovery in 1895. The amount of imports was so high in 1891 that only in 1907 did the economy reach that level again. GDP recovered to its 1891 level in 1901.

Other conspicuous features of the GDP series are an acceleration that took place around 1895 and a slowdown at the beginning of the 1980s. The second feature is widely known. It corresponds to the beginning of the "lost decades".

The GDP surge happened close to 1895. Both Baer (1996) and Prado Jr. (1979) state that an industrial surge started in the 1880s. Additional evidence of that industrial 
take-off is provided in Table 7.6 of IBGE (1990). Industrial machinery and equipment imports displayed a boom after 1880. It is well known that industrialization is often accompanied by a rise in GDP's growth. For evidence on this growth-stylized fact, see Baldwin, Martin and Ottaviano (1998).

\subsection{The Population Series}

We did not find any population series for the entire 1850-2000 period that was suited to the purposes of this paper. All series to which we had access use, at least for some sub-period, geometric interpolation for years between censuses. We explain next why such estimations are not appropriate for our goals.

One of the tasks we propose to carry out in this paper is to document the statistical properties of the Brazilian per capita GDP. The use of population data based on geometric interpolation would necessarily introduce spurious breaks in the per capita GDP series. For instance, consider the sub-period 1960-2000. During these years, the Brazilian population grew at decreasing rates. Had we used geometric interpolation for the years between 1960 and 1970 and 1970 and 1980, the population growth rate would decrease in 1971 and be constant up to 1980. That would have introduced a spurious positive break in the per capita GPD series exactly in 1971.

To overcome these problems, we decided to construct our own population series using cubic spline interpolation. ${ }^{4}$ For the purposes of this paper, this method has the advantage of generating a population series that has a smooth growth rate and exactly matches the original figures for the years used as interpolation nodes. Therefore, our population series exactly matches the long run evolution of the Brazilian population.

We detail next how we construct our population series. Our basic source for population figures is the data CD that accompanies IBGE (2003). The file 'populacao_al952aeb_32.xls' located in the folder 'populacao $\backslash 1952$ ' contains population estimations for each year in the period 1851-1950. We picked the years 1851, 1860, $1870,1880,1890,1900,1910,1920,1930,1940$ and 1950 as interpolation nodes. ${ }^{5}$ The file 'populacao2000aeb_s2_002a_a_002b.xls' in the folder 'populacao $\mid 2000$ ' contains the results of several population censuses. We took the results for 1960, 1970, 1980, 1991 and 2000 as interpolation nodes as well.

4 Details of the spline interpolation method are available in several numerical analysis textbooks, such as Burden and Faires (1997).

5 There are other population figures available for the period 1851-1950. We decided on the one provided in that file because it was the latest re-estimation carried out by IBGE that fully covered that period. 
In Figure 2 we plot the first difference of the log of our population series. The horizontal lines correspond to the arithmetic averages of the first differences for each decennium. Since our population series exactly matches the IBGE data at the interpolation nodes, these averages correspond to both IBGE and our data.

FIGURE 2 - FIRST DIFFERENCE OF THE LOG OF THE BRAZILIAN POPULATION

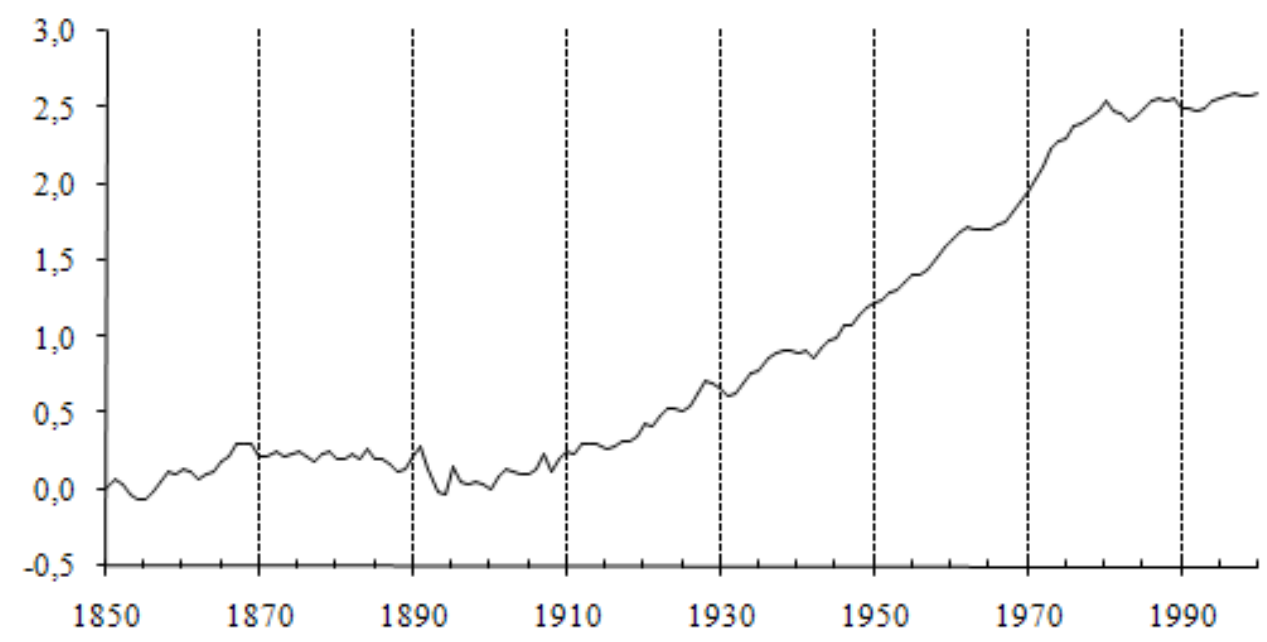

\subsection{The Per Capita GDP Series}

We obtain the per capita GDP series by taking the ratio of GDP to population. Figure 3 plots the logarithm of real per capita GDP. In Table 2 we present the average growth rate for each decade. 
FIGURE 3 - LOG OF REAL PER CAPITA BRAZILIAN GDP

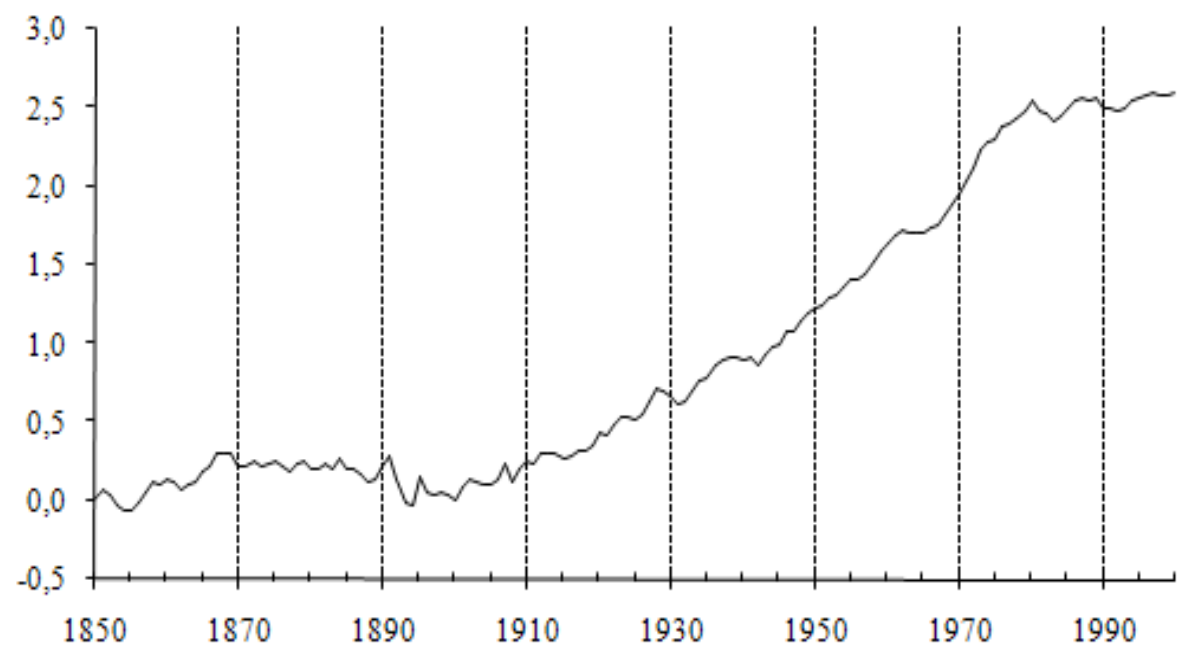

TABLE 2 - REAL PER CAPITA GDP - AVERAGE GROWTH RATE

\begin{tabular}{lccccc}
\hline period & rate & period & rate & period & rate \\
\hline $1851-1860$ & 1.35 & $1901-1910$ & 2.43 & $1951-1960$ & 4.22 \\
$1861-1870$ & 0.89 & $1911-1920$ & 1.82 & $1961-1970$ & 3.19 \\
$1871-1880$ & -0.22 & $1921-1930$ & 2.41 & $1971-1980$ & 6.00 \\
$1881-1890$ & 0.22 & $1931-1940$ & 2.28 & $1981-1990$ & -0.37 \\
$1891-1900$ & -2.15 & $1941-1950$ & 3.45 & $1991-2000$ & 1.01 \\
\hline
\end{tabular}

Some selected characteristics of the per capita GDP series deserve a few words. From the end of World War II up to 1980, Brazil experienced high growth rates. Afterwards, real per capita GPD stagnated. These facts are widely known. For instance, Abreu (2003) also reported them.

The behavior of the average GDP for $1850-1925$ period has not been studied as often as for the post World War II period. According to Contador and Haddad (1975), per capita GDP in 1910 was about the same as in 1861. Our series also displays this fact. Additionally, we calculate that the per capita GDP was about the same in 1891 and 1916. The same fact is observed for 1885 and 1909. The average Brazilian was poorer in 1916 than in 1869. 
The facts mentioned above are consequences of a major decline in the Brazilian per capita GDP during the 1870-1900 period. According to our series, per capita GDP in 1900 was only $80 \%$ of the 1870 figure. Using Contador and Haddad's (1975) series, the equivalent figure is $68 \%$. Therefore, the available evidence suggests that the Brazilian economy suffered a severe decline in the thirty years that followed the end of the Paraguayan War in 1870.

\section{UNIT ROOT PROPERTIES}

We perform unit root tests to detect the presence of stochastic trends in order to build a time series model for the level of the series. If one of the series follows a unit root process, we need to adopt some detrending procedure. After we perform a logarithmic transformation of our data, both GDP and per capita GDP are analyzed. In addition to the ADF test, we conduct unit root tests allowing for breaks in the data, since Cati, Garcia and Perron (1999) showed that some Brazilian time series are better characterized by the presence of structural breaks.

First, we present results based on a simple ADF test without breaks. We search for the optimal lag length using three information criteria (AIC, Schwarz and HannanQuinn). For all the criteria employed, after searching for up to 10 lags, we find that the optimal lag length is zero for both series. We allow for a constant and a linear time trend as deterministic components since both series are clearly trended, as shown in Figures 1 and 3. The test results are summarized in Table 3.

TABLE 3 - UNIT ROOT TEST WITHOUT BREAK

\begin{tabular}{lccccc}
\hline Variable & $\begin{array}{c}\text { Number of } \\
\text { Lags }\end{array}$ & $\begin{array}{c}\text { Deterministic } \\
\text { Component }\end{array}$ & $\begin{array}{c}\text { Test } \\
\text { Statistic }\end{array}$ & $\begin{array}{c}5 \% \text { Critical } \\
\text { Level }\end{array}$ & $\begin{array}{c}10 \% \text { Critical } \\
\text { Level }\end{array}$ \\
\hline GDP & 0 & constant and trend & -1.433 & -3.41 & -3.13 \\
Per Capita GDP & 0 & constant and trend & -1.625 & -3.41 & -3.13 \\
\hline
\end{tabular}

Second, we allow one endogenous break, as in Perron (1989). The break takes the form of either an impulse dummy or a level shift dummy. We employ a test strategy developed by Saikkonen and Lütkepohl (2002) and Lanne, Lütkepohl and Saikkonen (2002). As in the ADF test, we search for the optimal number of lags using the same information criteria. We allow for a constant and a time trend as in the ADF test. These test results are summarized in Table 4. 
TABLE 4 - UNIT ROOT TEST WITH AN ENDOGENOUS BREAK

\begin{tabular}{lccccccc}
\hline Variable & $\begin{array}{c}\text { Number of } \\
\text { Lags }\end{array}$ & $\begin{array}{c}\text { Dummy } \\
\text { Shift }\end{array}$ & $\begin{array}{c}\text { Endogenous } \\
\text { Break Date }\end{array}$ & $\begin{array}{c}\text { Deterministic } \\
\text { Component }\end{array}$ & $\begin{array}{c}\text { Test } \\
\text { Statistic }\end{array}$ & $\begin{array}{c}5 \% \text { Critical } \\
\text { Level }\end{array}$ & $\begin{array}{c}10 \% \text { Critical } \\
\text { Level }\end{array}$ \\
\hline GDP & 0 & impulse & 1895 & constant and trend & -0.913 & -3.03 & -2.76 \\
Per Capita GDP & 0 & impulse & 1895 & constant and trend & -0.786 & -3.03 & -2.76 \\
GDP & 0 & level & 1893 & constant and trend & -1.013 & -3.03 & -2.76 \\
Per Capita GDP & 0 & level & 1893 & constant and trend & -0.849 & -3.03 & -2.76 \\
\hline
\end{tabular}

We cannot reject the null hypothesis of the existence of a unit root. Hence, the levels of both GDP and per capita GDP are non-stationary and we must filter the data. In Section III we adopt the HP filter, while in Section IV we build a univariate time series model for the growth rate of per capita GDP.

\section{CYCLICAL PROPERTIES OF PER CAPITA GDP}

To extract the cyclical component of the per capita GDP series, we detrend the natural logarithm of that series with the well-known Hodrick-Prescott (HP) filter. ${ }^{6}$ Following a standard procedure of the related literature, we adopt the value of 100 for the smoothing parameter $\lambda .^{7}$

Figure 4 presents the time path of the cyclical component of Brazilian per capita GDP.

6 Hodrick and Prescott (1997) provide a detailed explanation of the HP filtering procedure.

7 Ravn and Uhlig (1997) argue that instead of 100, 6.25 would constitute a more appropriate value for $\lambda$ when working with annual data. We also used that alternative figure. However, except that the cyclical component became less volatile, we did not find any major difference in the results. 
FIGURE 4 - CYCLICAL COMPONENT OF THE LOG OF PER CAPITA GDP

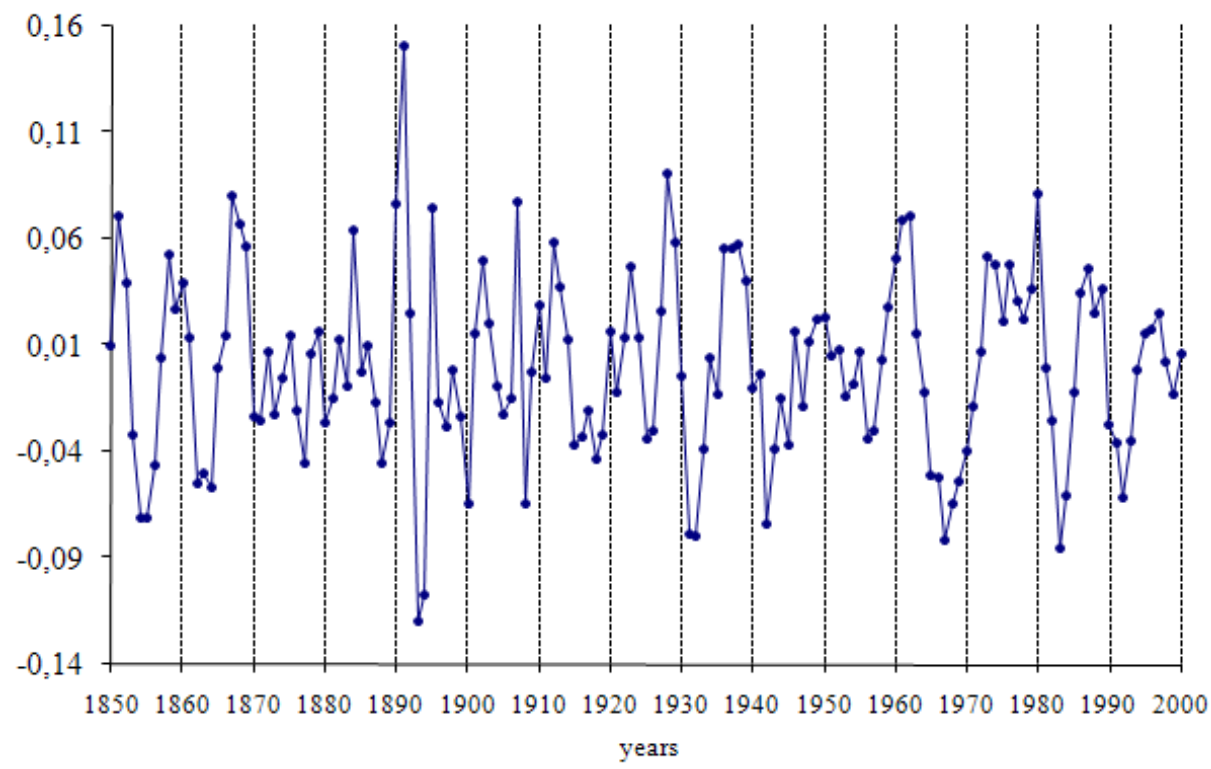

Next we study some of the properties of the cyclical component of per capita GDP. First we look into its volatility and persistence. Then, we study its evolution across the cyclical phases (i.e., expansion and recession).

Following the standard approach of the business cycle literature, we used the standard deviation and first order serial autocorrelation of the cyclical component of per capita GDP to measure its volatility and persistence. We report these statistics in Table 5 for the whole sample and some selected sub-periods.

TABLE 5 - BUSINESS-CYCLE VOLATILITY AND PERSISTENCE

\begin{tabular}{lcc}
\hline years & standard deviation $(\%)$ & autocorrelation \\
\hline $1850-1889$ & 3.96 & 0.512 \\
$1890-1945$ & 5.11 & 0.343 \\
$1946-2000$ & 3.88 & 0.715 \\
$1850-2000$ & 4.37 & 0.470 \\
\hline
\end{tabular}

The greatest volatility occurred between 1890-1945. Recall that in 1889 the Republic was proclaimed in Brazil. Hence, the volatility of per capita output fluc- 
tuations seems to have increased slightly after the fall of the Monarchy up to the end of World War II. For the other two sub-periods, 1850-1889 and 1946-2000, the volatility was roughly the same. Concerning the autocorrelation, the main conclusion is that an appreciable increase in persistence happened after World War II.

It is important to explain how we selected the sub-periods in Table 5. The subperiod 1850-1889 corresponds to the Imperial years of our sample. Hence, we have 111 Republican years (from 1890 to 2000). The end of World War II in 1945 divides these 111 years into two sub-periods of roughly the same duration. In summary, we select two major historical events (the advent of the Republic and the end of World War II) to divide our sample into three sub-periods.

Backus and Kehoe (1992) studied the output volatility, over a hundred years, of ten countries (Australia, Canada, Denmark, Germany, Italy, Japan, Norway, Sweden, the United Kingdom and United States). They focused on three sub-periods, which they labeled as prewar, interwar and postwar. There were slight differences in terms of data coverage for each country, but broadly speaking, the prewar period covers data prior to the beginning of World War I, interwar refers to the period between the end of World War I and beginning of World War II, and postwar deals with data after the end of World War II up to 1985. Their main conclusion was that, except for Australia, all countries in their sample had higher output volatility in the interwar period than in the other periods.

For comparison purposes, we carried out the same exercise with Brazilian per capita GDP. Table 6 contains the results of that exercise.

TABLE 6 - BUSINESS-CYCLE VOLATILITY

\begin{tabular}{lc}
\hline Period & volatility \\
\hline prewar (1850-1914) & 4.80 \\
interwar (1920-1939) & 4.64 \\
postwar (1950-1985) & 4.35 \\
\hline
\end{tabular}

We chose the sub-periods in Table 6 to match those of Backus and Kehoe (1992). The Brazilian economy did not display the highest variability during the interwar era. In fact, the volatility reached its maximum in the prewar period. However, it varied very little across the three periods. This is an important difference from other countries. For instance, in Canada and the United States the volatility practically halved from the prewar to the postwar periods. 
We obtain another interesting finding when comparing the data in Table 6 to equivalent statistics that Backus and Kehoe (1992) reported for the United States. That country had prewar, interwar and postwar volatilities of, respectively, 4.28, 9.33 and 2.26. So, the Brazilian volatility was similar to the US one in the prewar period and almost its double in the postwar years.

We now turn to the problem of dating recessions, expansions and turning points. We follow Canova $(1994,1999)$ and Harding and Pagan (2002) and adopt very simple dating rules.

Let $y_{t}^{C}$ denote the cyclical component of per capita GDP. We say that an expansion takes place at year $t$ if $y_{t}^{C}-y_{t-1}^{C}>0$. Similarly, a recession happens whenever $y_{t}^{C}-y_{t-1}^{C} \leq 0$. The last year of an expansion corresponds to a peak and the last year of a recession corresponds to a trough. A turning point takes place whenever the economy hits a peak or a trough.

Our simple dating procedure is in line with the business cycle literature. There are alternative procedures that rely on econometric techniques. Chauvet (2002) and Duarte, Issler and Spacov (2004) adopted some of these alternative procedures to create chronologies of the Brazilian business cycle. Despite these differences, it turned out that our chronology is similar to the one Chauvet constructed using yearly data, as we did.

We present in Table 7 the evolution of Brazilian per capita GDP over the businesscycle phases. A plus sign means expansion and minus sign means recession.

The two longest expansions lasted six years each, from 1957 to 1962 and from 1968 to 1973. The longest recession lasted for five years, from 1963 to 1967. 
TABLE 7 - CYCLICAL PHASES OF PER CAPITA GDP

\begin{tabular}{|c|c|c|c|c|c|c|c|c|c|c|c|}
\hline year & phase & year & phase & year & phase & year & phase & year & phase & year & phase \\
\hline 1851 & + & 1876 & - & 1901 & + & 1926 & + & 1951 & - & 1976 & + \\
\hline 1852 & - & 1877 & - & 1902 & + & 1927 & + & 1952 & + & 1977 & - \\
\hline 1853 & - & 1878 & + & 1903 & - & 1928 & + & 1953 & - & 1978 & - \\
\hline 1854 & - & 1879 & + & 1904 & - & 1929 & - & 1954 & + & 1979 & + \\
\hline 1855 & - & 1880 & - & 1905 & - & 1930 & - & 1955 & + & 1980 & + \\
\hline 1856 & + & 1881 & + & 1906 & + & 1931 & - & 1956 & - & 1981 & - \\
\hline 1857 & + & 1882 & + & 1907 & + & 1932 & - & 1957 & + & 1982 & - \\
\hline 1858 & + & 1883 & - & 1908 & - & 1933 & + & 1958 & + & 1983 & - \\
\hline 1859 & - & 1884 & + & 1909 & + & 1934 & + & 1959 & + & 1984 & + \\
\hline 1860 & + & 1885 & - & 1910 & + & 1935 & - & 1960 & + & 1985 & + \\
\hline 1861 & - & 1886 & + & 1911 & - & 1936 & + & 1961 & + & 1986 & + \\
\hline 1862 & - & 1887 & - & 1912 & + & 1937 & + & 1962 & + & 1987 & + \\
\hline 1863 & + & 1888 & - & 1913 & - & 1938 & + & 1963 & - & 1988 & - \\
\hline 1864 & - & 1889 & + & 1914 & - & 1939 & - & 1964 & - & 1989 & + \\
\hline 1865 & + & 1890 & + & 1915 & - & 1940 & - & 1965 & - & 1990 & - \\
\hline 1866 & + & 1891 & + & 1916 & + & 1941 & + & 1966 & - & 1991 & - \\
\hline 1867 & + & 1892 & - & 1917 & + & 1942 & - & 1967 & - & 1992 & - \\
\hline 1868 & - & 1893 & - & 1918 & - & 1943 & + & 1968 & + & 1993 & + \\
\hline 1869 & - & 1894 & + & 1919 & + & 1944 & + & 1969 & + & 1994 & + \\
\hline 1870 & - & 1895 & + & 1920 & + & 1945 & - & 1970 & + & 1995 & + \\
\hline 1871 & - & 1896 & - & 1921 & - & 1946 & + & 1971 & + & 1996 & + \\
\hline 1872 & + & 1897 & - & 1922 & + & 1947 & - & 1972 & + & 1997 & + \\
\hline 1873 & - & 1898 & + & 1923 & + & 1948 & + & 1973 & + & 1998 & - \\
\hline 1874 & + & 1899 & - & 1924 & - & 1949 & + & 1974 & - & 1999 & - \\
\hline 1875 & + & 1900 & - & 1925 & - & 1950 & + & 1975 & - & 2000 & + \\
\hline
\end{tabular}

Legend: '+' means expansion and ' - ' means recession.

Table 8 contains information on some selected features of the chronology of recessions and expansions of the Brazilian economy. We compute these figures using the 1852-1999 period. In other words, we removed from the calculations the two end years of the period covered in Table 7. Had we proceed differently, we would have included in our calculations two one-year expansions that we could not be sure really lasted one year. For instance, if the Brazilian economy experienced an expansion in 2001 it would be definitively wrong to compute the expansion in 2000 as a oneyear event. 
TABLE 8 - FEATURES OF EXPANSIONS AND RECESSIONS

\begin{tabular}{lc}
\hline Feature & Value \\
\hline years in expansion & 79 \\
years in recession & 69 \\
number of expansions & 35 \\
number of recessions & 37 \\
average expansion length & 2.26 \\
average recession length & 1.86 \\
\hline
\end{tabular}

There were 79 years of expansion and 69 of recession. The number of recessions (37) was slightly higher than the number of expansions (35). The average expansion lasted $21 \%$ longer than the average recession. So, expansions were more frequent and lasted longer than recessions.

\section{GROWTH PROPERTIES OF PER CAPITA GDP}

We briefly discussed the evolution of Brazilian per capita GDP and its growth rate in Section I.3. We take the discussion a step further in this section. We first investigate if the volatility of the growth rates has been increasing or decreasing over time. Then, we try to identify whether changes in the volatility of per capita GDP impact its growth rate. Finally, we assess if there was a change in the persistence of the per capita GDP growth rate. ${ }^{8}$

\subsection{Volatility Trend and the Fischer Black Hypothesis}

We carry out two tasks in this subsection. The first is to assess how per capita output volatility changes over time. The second is to study the role of volatility in the evolution of the growth rate of per capita output.

We measure volatility as the squared growth rate of per capita output. To find the trend, we just fit a quadratic polynomial to the volatility series of per capita output. We plot the volatility and its trend in Figure 5.

8 We carried out similar exercises for the GDP growth rate. The results were qualitatively similar. 
FIGURE 5 - PER CAPITA GDP GROWTH RATES - VOLATILITY AND VOLATILITY TREND

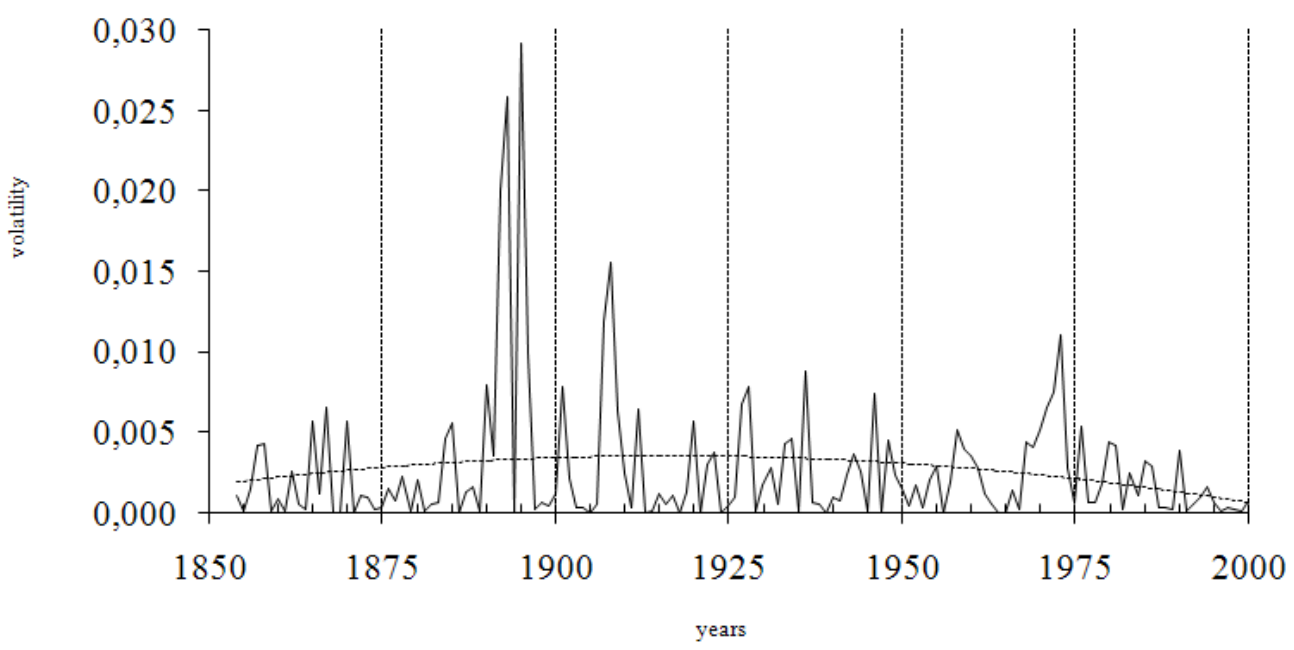

The trend shows a small volatility phase from 1850 to 1875 approximately, followed by a moderate volatility phase from 1875 to 1975 (a period in which volatility was increasing) and then by another small volatility phase, beginning approximately in 1975. One plausible explanation for the observed pattern is that at the beginning, Brazil had an unsophisticated economic structure, and therefore was subject to few macroeconomic shocks. Afterwards, it became an industrialized economy, but without efficient institutions to conduct macroeconomic policies. The last phase may be due to improving institutional arrangements. Still, it is worth noting that the change in volatility patterns is not abrupt, suggesting a smooth pattern rather than breaks.

Interestingly, comparing the results reported in Table 2 with Figure 5, we see that periods of high average growth seem to coincide with periods of high volatility. This observation leads us to the second issue we discuss in this subsection.

Fischer Black (1987) argues that a positive relationship between output volatility and growth must be verified. The reason is that economies face a positive trade-off between risk (volatility) and return (output growth rates) in choosing their aggregate technologies.

As Caballero (1991) pointed out, there is an alternative view on the relation between growth and volatility. It is often argued that large swings in the economy 
make investment extremely risky, and as a result induce less investment, less capital accumulation and consequently less output growth.

Some authors have emphasized a possible relation between instability and growth while studying the performance of the Brazilian economy in the 1980s and 90s. Baer (1996) argued that the generalized uncertainty that affected the country was responsible for the stagnation during those two decades. Pinheiro, Giambiagi and Gostkorzewicz (1999) suggested that the low investment rates observed in the Brazilian economy during the 1980s was a consequence of the economic instability prevailing at that time.

Caporale and MacKiernan (1998) tested the Fischer Black hypothesis for the United States from 1871 and 1993 and found that variability significantly increases output growth rates. We carry out a similar exercise with the Brazilian per capita GDP series. We estimate a GARCH $(1,1)$ in mean model for per capita output.

The GARCH $(1,1)$ is a model for the conditional variance of a time series. In order to capture the effect of volatility on output growth, we introduce the conditional standard deviation in the equation for the mean of per capita output growth process.

Before presenting the results, some notation is in order. Let $y_{t}$ be natural log of the per capita output. As usual, $\Delta$ denotes the first difference operator. The conditional variance is denoted by $\sigma_{t}$ and $\varepsilon_{t}$ stands for the residual in the mean equation.

The model estimated has a mean equation and an equation for conditional variance, which are, respectively

$$
\Delta y_{t}=\gamma_{0}+\gamma_{1} \Delta y_{t-1}+\gamma_{2} \sigma_{t}+\varepsilon_{t}
$$

and

$$
\sigma_{t}=\omega+\alpha \varepsilon_{t-1}^{2}+\beta \sigma_{t-1}^{2}
$$

We report the estimation results in Table 9. 
TABLE 9 - ESTIMATION RESULTS - GARCH(1,1) IN MEAN

\begin{tabular}{cccc}
\hline parameters & estimate & standard deviation & $Z$ statistics \\
$\gamma_{0}$ & 0.0621 & 0.0319 & 1.9452 \\
$\gamma_{1}$ & 0.1677 & 0.0863 & 1.9411 \\
$\gamma_{2}$ & -0.9859 & 0.6863 & -1.4364 \\
$\omega$ & 0.0002 & 0.0001 & 1.2941 \\
$\alpha$ & 0.1035 & 0.0568 & 1.8199 \\
$\beta$ & 0.8214 & 0.0777 & 10.5631 \\
\hline
\end{tabular}

The estimation results suggest that volatility does not enter in a statistically significant way in the mean equation. Moreover, the point estimate contradicts the Fischer Black hypothesis. Therefore, that conjecture seems not to hold for Brazil, and if volatility influences growth at all, it is in a negative fashion as other authors suggested.

\subsection{Are Pre and Post World War II Per Capita GDP Growth So Different?}

Table 5 suggests that business cycles became more persistent after World War II. In this subsection we fit a simple AR (1) - GARCH $(1,1)$ model, similar to the one in the previous subsection, allowing for a dummy variable, denoted by $d$, associated with observations from 1946 to 2000, in the mean and in the conditional variance equation. The goal is to verify if changes in the dynamics of per capita GDP growth are related to volatility or to persistence.

The dummy is significant in the conditional variance equation only when we specify an $\mathrm{ARCH}(\mathrm{l})$ process. With a GARCH $(1,1)$ process, the dummy is not significant, so we drop that variable from the conditional variance equation.

The estimated equations are

$$
\Delta y_{t}=\gamma_{0}+\gamma_{1} d_{t}+\gamma_{2} \Delta y_{t-1}+\gamma_{3} d_{t} \Delta y_{t-1}+\varepsilon_{t}
$$

and

$$
\sigma_{t}=\omega+\alpha \varepsilon_{t-1}^{2}+\beta \sigma_{t-1}^{2}
$$


We report the estimation results in Table 10.

TABLE 10 - ESTIMATION RESULTS - GARCH(1,1) WITH DUMMY

\begin{tabular}{cccc}
\hline parameters & estimate & standard deviation & $Z$ statistics \\
\hline$\gamma_{0}$ & 0.0106 & 0.0049 & 2.1605 \\
$\gamma_{1}$ & 0.0066 & 0.0117 & 0.5629 \\
$\gamma_{2}$ & 0.0032 & 0.0986 & 0.0325 \\
$\gamma_{3}$ & 0.3776 & 0.2511 & 1.5133 \\
$\omega$ & 0.0006 & 0.0005 & 1.2338 \\
$\alpha$ & 0.1929 & 0.0983 & 1.9622 \\
$\beta$ & 0.5276 & 0.2810 & 1.8777 \\
\hline
\end{tabular}

The estimation provides evidence that per capita GDP growth became much more persistent after the World War II. Therefore, the pre and post World War II dynamics of the series are very different. Furthermore, that difference is related to a change in persistence rather than a dramatic change in volatility, since the dummy variable in the conditional variance is not significant.

\section{CONCLUSION}

We had two major aims in this paper. First, we wanted to verify whether the Brazilian business cycles from 1850 to 2000 displayed statistical regularities similar to those of some developed countries, as reported in Backus and Kehoe (1992). Second, we wanted to investigate if relevant structural breaks took place in that period and to assess the impact of these changes for the relation between growth and volatility rates.

Contrary to the international evidence, the volatility of Brazilian business cycles does not appear to have changed in an appreciable way. However, the business cycle and growth oscillations seemed to be a little higher around the 1950s than in the vicinity of the end-points of our sample. On the other hand, persistence seemed to be higher after World War II than before. We did not find evidence that growth and volatility are related in a statistically significant way.

The relevance of our findings is two-fold. An important question in the field of business cycles is whether this phenomenon is homogenous across nations. We ob- 
tained evidence that the Brazilian cyclical oscillations had some distinctive features. On the other hand, the finding that volatility and growth rates may not be strongly correlated has some policy implications. It suggests that a policy aimed at smoothing out the business cycles is unlikely to foster long-run growth. So, Brazilian policymakers should focus on policies related to education and infrastructure and be less concerned with managing cyclical expansions and recessions. 


\section{APPENDIX}

\section{TABLE AI - POPULATION AND GDP}

\begin{tabular}{|c|c|c|c|c|c|c|c|}
\hline \multirow{2}{*}{ year } & \multirow{2}{*}{ population } & \multicolumn{2}{|c|}{ real GDP indexes } & \multirow{2}{*}{ year } & \multirow{2}{*}{ population } & \multicolumn{2}{|c|}{ real GDP indexes } \\
\hline & & aggregate & per capita & & & aggregate & per capita \\
\hline 1850 & 7213456 & 1 & 1 & 1888 & 13610080 & 2.14000 & 1.13422 \\
\hline 1851 & 7344000 & 1.08492 & 1.06563 & 1889 & 13895390 & 2.20046 & 1.14232 \\
\hline 1852 & 7470623 & 1.07269 & 1.03576 & 1890 & 14199000 & 2.45862 & 1.24904 \\
\hline 1853 & 7593955 & 1.01970 & 0.96861 & 1891 & 14522204 & 2.66922 & 1.32585 \\
\hline 1854 & 7714625 & 1.00272 & 0.93758 & 1892 & 14863513 & 2.37098 & 1.15067 \\
\hline 1855 & 7833263 & 1.02718 & 0.94590 & 1893 & 15220747 & 2.06730 & 0.97974 \\
\hline 1856 & 7950498 & 1.08289 & 0.98250 & 1894 & 15591724 & 2.11553 & 0.97874 \\
\hline 1857 & 8066960 & 1.17256 & 1.04850 & 1895 & 15974261 & 2.57138 & 1.16115 \\
\hline 1858 & 8183278 & 1.27039 & 1.11983 & 1896 & 16366178 & 2.38591 & 1.05160 \\
\hline 1859 & 8300081 & 1.27786 & 1.11057 & 1897 & 16765292 & 2.40561 & 1.03504 \\
\hline 1860 & 8418000 & 1.33493 & 1.14391 & 1898 & 17169421 & 2.52654 & 1.06149 \\
\hline 1861 & 8537663 & 1.34308 & 1.13477 & 1899 & 17576385 & 2.53605 & 1.04081 \\
\hline 1862 & 8659700 & 1.29553 & 1.07917 & 1900 & 17984000 & 2.50616 & 1.00523 \\
\hline 1863 & 8784741 & 1.34580 & 1.10508 & 1901 & 18390686 & 2.80018 & 1.09833 \\
\hline 1864 & 8913415 & 1.38316 & 1.11936 & 1902 & 18797260 & 2.99619 & 1.14979 \\
\hline 1865 & 9046351 & 1.51360 & 1.20693 & 1903 & 19205140 & 3.01019 & 1.13063 \\
\hline 1866 & 9184179 & 1.58901 & 1.24804 & 1904 & 19615745 & 3.02419 & 1.11211 \\
\hline 1867 & 9327528 & 1.74934 & 1.35285 & 1905 & 20030492 & 3.09419 & 1.11429 \\
\hline 1868 & 9477029 & 1.77448 & 1.35065 & 1906 & 20450800 & 3.23420 & 1.14077 \\
\hline 1869 & 9633309 & 1.79962 & 1.34756 & 1907 & 20878087 & 3.68223 & 1.27222 \\
\hline 1870 & 9797000 & 1.69704 & 1.24952 & 1908 & 21313771 & 3.31821 & 1.12302 \\
\hline 1871 & 9968498 & 1.72625 & 1.24916 & 1909 & 21759269 & 3.66823 & 1.21606 \\
\hline 1872 & 10147273 & 1.81457 & 1.28993 & 1910 & 22216000 & 3.93425 & 1.27744 \\
\hline 1873 & 10332563 & 1.79215 & 1.25115 & 1911 & 22685073 & 3.94825 & 1.25547 \\
\hline 1874 & 10523606 & 1.85193 & 1.26941 & 1912 & 23166360 & 4.36828 & 1.36018 \\
\hline 1875 & 10719641 & 1.91987 & 1.29192 & 1913 & 23659426 & 4.43828 & 1.35317 \\
\hline 1876 & 10919903 & 1.88183 & 1.24310 & 1914 & 24163832 & 4.49428 & 1.34165 \\
\hline 1877 & 11123633 & 1.86485 & 1.20932 & 1915 & 24679144 & 4.43828 & 1.29726 \\
\hline 1878 & 11330067 & 1.99257 & 1.26860 & 1916 & 25204924 & 4.63429 & 1.32630 \\
\hline 1879 & 11538443 & 2.04488 & 1.27839 & 1917 & 25740737 & 4.88631 & 1.36932 \\
\hline 1880 & 11748000 & 1.98985 & 1.22180 & 1918 & 26286144 & 4.98432 & 1.36780 \\
\hline 1881 & 11958433 & 2.04284 & 1.23226 & 1919 & 26840711 & 5.27834 & 1.41856 \\
\hline 1882 & 12171271 & 2.12776 & 1.26104 & 1920 & 27404000 & 5.81037 & 1.52944 \\
\hline 1883 & 12388502 & 2.11010 & 1.22865 & 1921 & 27975723 & 5.92238 & 1.52707 \\
\hline 1884 & 12612111 & 2.29828 & 1.31449 & 1922 & 28556179 & 6.38441 & 1.61274 \\
\hline 1885 & 12844087 & 2.17260 & 1.22017 & 1923 & 29145817 & 6.93045 & 1.71525 \\
\hline 1886 & 13086416 & 2.22016 & 1.22379 & 1924 & 29745085 & 7.02846 & 1.70447 \\
\hline 1887 & 13341084 & 2.18280 & 1.18023 & 1925 & 30354431 & 7.02846 & 1.67025 \\
\hline
\end{tabular}

(Continued at next page) 
TABLE AI - POPULATION AND GDP (continued)

\begin{tabular}{|c|c|c|c|c|c|c|c|}
\hline \multirow{2}{*}{ year } & \multirow{2}{*}{ population } & \multicolumn{2}{|c|}{ real GDP indexes } & \multirow{2}{*}{ year } & \multirow{2}{*}{ population } & \multicolumn{2}{|c|}{ real GDP indexes } \\
\hline & & aggregate & per capita & & & aggregate & per capita \\
\hline 1926 & 30974302 & 7.39248 & 1.7216 & 1964 & 78825606 & 60.37461 & 5.52498 \\
\hline 1927 & 31605147 & 8.19053 & 1.86938 & 1965 & 81115836 & 61.82360 & 5.49784 \\
\hline 1928 & 32247412 & 9.12859 & 2.04198 & 1966 & 83445179 & 65.96578 & 5.70244 \\
\hline 1929 & 32901548 & 9.22660 & 2.02287 & 1967 & 85812903 & 68.73634 & 5.77800 \\
\hline 1930 & 33568000 & 9.03059 & 1.94059 & 1968 & 88218276 & 75.47250 & 6.17126 \\
\hline 1931 & 34247323 & 8.73657 & 1.84017 & 1969 & 90660564 & 82.64239 & 6.57549 \\
\hline 1932 & 34940492 & 9.11459 & 1.88170 & 1970 & 93139037 & 91.23720 & 7.06616 \\
\hline 1933 & 35648587 & 9.92664 & 2.00865 & 1971 & 95652211 & 101.58616 & 7.66096 \\
\hline 1934 & 36372691 & 10.83670 & 2.14914 & 1972 & 98195605 & 113.71590 & 8.35358 \\
\hline 1935 & 37113882 & 11.15872 & 2.16881 & 1973 & 100763985 & 129.60056 & 9.27780 \\
\hline 1936 & 37873244 & 12.50281 & 2.38132 & 1974 & 103352118 & 140.16811 & 9.78303 \\
\hline 1937 & 38651855 & 13.07685 & 2.44049 & 1975 & 105954772 & 147.41011 & 10.03576 \\
\hline 1938 & 39450798 & 13.66489 & 2.49858 & 1976 & 108566714 & 162.53016 & 10.79893 \\
\hline 1939 & 40271152 & 14.00091 & 2.50787 & 1977 & 111182711 & 170.54993 & 11.06516 \\
\hline 1940 & 41114000 & 13.86090 & 2.43190 & 1978 & 113797531 & 179.02609 & 11.34820 \\
\hline 1941 & 41981380 & 14.54694 & 2.49953 & 1979 & 116405940 & 191.12747 & 11.84381 \\
\hline 1942 & 42879166 & 14.15491 & 2.38125 & 1980 & 119002706 & 208.71120 & 12.65122 \\
\hline 1943 & 43814191 & 15.35899 & 2.52866 & 1981 & 121583741 & 199.84097 & 11.85639 \\
\hline 1944 & 44793288 & 16.52106 & 2.66053 & 1982 & 124149534 & 201.49965 & 11.70773 \\
\hline 1945 & 45823289 & 17.05309 & 2.68448 & 1983 & 126701720 & 195.59571 & 11.13577 \\
\hline 1946 & 46911027 & 19.02722 & 2.92579 & 1984 & 129241933 & 206.15788 & 11.50641 \\
\hline 1947 & 48063335 & 19.48925 & 2.92499 & 1985 & 131771808 & 222.34127 & 12.17141 \\
\hline 1948 & 49287044 & 21.37971 & 3.12905 & 1986 & 134292979 & 238.99463 & 12.83743 \\
\hline 1949 & 50588988 & 23.02595 & 3.28326 & 1987 & 136807080 & 247.43114 & 13.04635 \\
\hline 1950 & 51976000 & 24.59171 & 3.41294 & 1988 & 139315746 & 247.28268 & 12.80374 \\
\hline 1951 & 53452954 & 25.79670 & 3.48125 & 1989 & 141820611 & 255.09681 & 12.97505 \\
\hline 1952 & 55016895 & 27.67986 & 3.62920 & 1990 & 144323309 & 244.00010 & 12.19542 \\
\hline 1953 & 56662911 & 28.98081 & 3.68939 & 1991 & 146825475 & 246.51864 & 12.11133 \\
\hline 1954 & 58386089 & 31.24131 & 3.85979 & 1992 & 149328743 & 245.17741 & 11.84351 \\
\hline 1955 & 60181517 & 33.99055 & 4.07416 & 1993 & 151834748 & 257.25164 & 12.22166 \\
\hline 1956 & 62044282 & 34.97628 & 4.06645 & 1994 & 154345124 & 272.30824 & 12.72657 \\
\hline 1957 & 63969470 & 37.66945 & 4.24776 & 1995 & 156861505 & 283.80997 & 13.05133 \\
\hline 1958 & 65952171 & 41.73775 & 4.56503 & 1996 & 159385526 & 291.35531 & 13.18613 \\
\hline 1959 & 67987471 & 45.82805 & 4.86235 & 1997 & 161918821 & 300.88668 & 13.40445 \\
\hline 1960 & 70070457 & 50.13589 & 5.16128 & 1998 & 164463024 & 301.28361 & 13.21450 \\
\hline 1961 & 72196914 & 54.44758 & 5.44006 & 1999 & 167019770 & 303.72994 & 13.11786 \\
\hline 1962 & 74365412 & 58.04112 & 5.63000 & 2000 & 169590693 & 316.97937 & 13.48256 \\
\hline 1963 & 76575220 & 58.38937 & 5.50033 & - & - & - & - \\
\hline
\end{tabular}




\section{REFERENCES}

ABREU, Marcelo P. O Brasil no século XX: a economia. In: IBGE (ed.). Estatísticas do século XX. Rio de Janeiro: IBGE, 2003.

BACKUS, David; KEHOE, Patrick. International evidence on the historical properties of business cycles. American Economic Review, v. 82, n. 4, p. 864-888, 1992.

BAER, Werner. A economia brasileira. São Paulo: Nobel, 1996.

BALDWIN, Richard; MARTIN, Phillipe; OTTAVIANO, Gianmarco. Global income divergence, trade and industrialization: the geography of growth take-offs. Working paper 6458. Cambridge: National Bureau of Economic Research, 1998.

BARRO, Robert J.; SALA-I-MARTIN, Xavier. Economic growth. New York: McGrawHill, 1995.

BLACK, Fischer. Business cycles and equilibrium. New York: Blackwell, 1987.

BURDEN, Richard; FAIRES, J. Douglas. Numerical analysis. Sixth edition. Pacific Grove: Brooks/Cole Publishing Company, 1997.

BURNS, Arthur F; MITCHELL, Wesley C. Measuring business cycles. New York: National Bureau of Economic Research, 1946.

CABALLERO, Ricardo J. On the sign of the investment-uncertainty relationship. American Economic Review, v. 81, n. 1, p. 279-288, 1991.

CANOVA, Fabio. Does detrending matter for the determination of the reference cycle and the selection of turning points?. Economic Journal, v. 109, n. 452, p. 126-150, 1999.

. Detrending and turning points. European Economic Review, v. 38, n. 3-4, p. 614-623, 1994.

CAPORALE, Tony; McKIERNAN, Barbara. The Fischer Black hypothesis: some time-series evidence. Southern Economic Journal, v. 64, n. 3, p. 765-771, 1998.

CATI, Regina; GARCIA, Marcio; PERRON, Pierre. Unit roots in the presence of abrupt governmental interventions with an application to Brazilian data. Journal of Applied Econometrics, v. 14, n. 1, p. 27-56, 1999.

CHAUVET, Marcelle. The Brazilian business and growth cycles. Revista Brasileira de Economia, v. 56, n. 1, p. 75-106, 2002.

CONTADOR, Cláudio; HADDAD, Cláudio. Produto real, moeda e preços: a experiência brasileira no período 1861-1970. Revista Brasileira de Estatística, v. 36, n. 143 , p. 407-440, 1975.

DUARTE, Angelo J. Mont'alverne; ISSLER, João Victor; SPACOV, Andrei. Indicadores coincidentes de atividade econômica e uma cronologia de recessóes para o Brasil. Pesquisa e Planejamento Econômico, v. 34, n. 1, p. 1-37, 2004. 
ELLERY Jr., Roberto; GOMES, Victor. Ciclo de negócios no Brasil durante o século XX: uma comparação com a evidência internacional. Economia, v. 6, n. 1, p. 45-66, 2005.

; SACHSIDA, Adolfo. Business cycle fluctuations in Brazil. Revista Brasileira de Economia, v. 56, n. 2, p. 269-308, 2002.

GOLDSMITH, Raymond. Brasil 1850-1984: desenvolvimento financeiro sob um século de inflação. São Paulo: Harper \& Row do Brasil, 1986.

HADDAD, Cláudio. Crescimento do produto real no Brasil, 1900-1947. Rio de Janeiro: FGV, 1978.

HARDING, Don; PAGAN, Adrian. Dissecting the cycle: a methodological investigation. Journal of Monetary Economics, v. 49, p. 365-381, 2002.

HODRICK, Robert J.; PRESCOTT, Edward C. Postwar U.S. business cycles: an empirical investigation. Journal of Money, Credit and Banking, v. 29, n. 1, p. 1-16, 1997.

IBGE. Estatísticas históricas do Brasil: séries econômicas, demográficas e sociais de 1550 a 1988. $2^{\text {nd }}$ edition. Rio de Janeiro: IBGE, 1990. . Estatísticas do século XX. Rio de Janeiro: IBGE, 2003.

KALDOR, Nicholas. Capital accumulation and economic growth. In: LUTZ, Friedrich A.; HAGUE, Douglas C. (eds.). The theory of capital. Londres: Palgrave Macmillan, 1961.

LANNE, Markku; LÜTKEPHOL, Helmut; SAIKKONEN, Pentti. Comparison of unit root tests for time series with level shifts. Journal of Time Series Analysis, v. 23 , n. 6, p. 667-685, 2002.

PERRON, Pierre. The Great Crash, the Oil Price Shock, and the unit root hypothesis. Econometrica, v. 57, n. 6, p. 1361-1401, 1989.

PINHEIRO, Armando C.; GIAMBIAGI, Fabio; GOSTKORZEWICZ, Joana. O desempenho macroeconômico do Brasil nos anos 90. In: GIAMBIAGI, Fabio; MOREIRA, Maurício M. (ed.). A economia brasileira nos anos 90. Rio de Janeiro: BNDES, 1999.

PRADO JR., Caio. História econômica do Brasil. $22^{\text {nd }}$ edition. São Paulo: Editora Brasiliense, 1979.

RAVN, Morten O.; UHLIG, Harald. On adjusting the HP-filter for the frequency of observations. Discussion Paper 50. Tilburg: Center for Economic Research, Tilburg University, 1997.

SAIKKONEN, Pentti; LÜTKEPOHL, Helmut. Testing for a unit root in a time series with a level shift at unknown time. Econometric Theory, v. 18, n. 2 p. 343$364,2002$. 